\title{
HUBUNGAN SUBSTRAT DASAR PERAIRAN DENGAN KEHADIRAN RUMPUT LAUT ALAM DI PERAIRAN UJUNG GENTENG, SUKABUMI, JAWA BARAT
}

\author{
Ofri Johan")\#, Erlania"), dan I Nyoman Radiarta"') \\ ") Balai Penelitian dan Pengembangan Budidaya Ikan Hias \\ ") Pusat Penelitian dan Pengembangan Perikanan Budidaya
}

(Naskah diterima: 18 September 2015; Revisi final: 5 November 2015; Disetujui publikasi: 9 November 2015)

\begin{abstract}
ABSTRAK
Keberadaan jenis-jenis rumput laut alam sangat terkait dengan kondisi habitat tempat tumbuhnya. Penelitian ini bertujuan untuk menganalisis hubungan distribusi jenis rumput laut alam dengan tipe substrat dasar perairan. Pengumpulan data lapangan telah dilakukan pada 146 titik pengamatan, menggunakan transek kuadrat berukuran $1 \mathrm{~m} \mathrm{x} 1 \mathrm{~m}$, yang disebar vertikal mulai dari garis pantai hingga ke arah tubir dengan jarak antar titik sekitar $50 \mathrm{~m}$. Lokasi pengamatan dikelompokkan menjadi tiga kawasan berdasarkan jarak dari garis pantai dengan perbedaan karakteristik antar masing-masing kawasan tersebut, yaitu kawasan 1, 2, dan 3 dengan jarak 0-100 m, 100-300 m, dan > $300 \mathrm{~m}$ dari garis pantai. Hasil penelitian menunjukkan bahwa sebanyak 24 genus dari 34 spesies rumput laut yang termasuk dalam kelompok alga coklat, merah, dan hijau ditemukan pada ketiga kawasan dengan persentase total tutupan masing-masing $25,88 \% ; 27,72 \%$; dan $46,40 \%$. Tutupan rumput laut tertinggi ditemukan pada kawasan 1, yang dicirikan oleh substrat pasir yang berasosiasi dengan lamun, dan diikuti oleh kawasan 2 dan 3. Hasil analisis diskriminan menunjukkan hubungan yang signifikan antara distribusi alga merah dengan tipe substrat pasir; alga coklat dengan tipe substrat batu karang, pecahan karang, dan karang hidup; sedangkan alga hijau tersebar hampir di seluruh kawasan dengan tipe substrat yang berbeda. Informasi keterkaitan substrat dan keberadaan jenis rumput laut sangat penting dalam mendukung pengembangan teknologi budidaya rumput laut.
\end{abstract}

KATA KUNCI: tipe substrat, rumput laut, perairan Ujung Genteng, Jawa Barat

ABSTRACT: $\quad$ Relationship between bottom substrate types with wild seaweed species occurrence in Ujung Genteng coastal waters, Sukabumi, West Java. By: Ofri Johan, Erlania, and I Nyoman Radiarta

The existence of wild seaweed is closely related to condition of their habitat or substrate types. This research was aimed to analyze the relationship between substrate types and seaweed species occurance. Field sampling was conducted at 146 sites, using $1 \mathrm{~m} \times 1 \mathrm{~m}$ quadrate transect, which were distributed on vertical position from the coastline to the reef edge area, and approximately $50 \mathrm{~m}$ distance of each sites. The study locations were grouped into three area based on the distance from the coastline; those were area 1, 2, and 3 which were 0-100 m, 100-300 m, and > $300 \mathrm{~m}$ from the coastline, respectively. The results showed that 24 genus of 34 species of seaweed which belong to group of brown, red, and green algae were found in the three of study area, with total coverage of each group about $25.88 \%, 27.72 \%$, and $46.40 \%$, respectively. The highest seaweed coverage was found at area 1, which was characterized by sand substrate associated with seagrass population, then followed by area 2 and 3. Discriminant analysis result showed clearly relationship between red algae and sand, while green and brown algae close related to rock, rubble, and live coral substrate. These relationship information is important for supporting of seaweed aquaculture technology development.

KEYWORDS: $\quad$ substrate types, seaweed, Ujung Genteng coastal waters, West Java

\section{PENDAHULUAN}

Rumput laut merupakan salah satu sumberdaya alam yang sangat melimpah di perairan Indonesia. Hasil

\# Korespondensi: Balai Penelitian dan Pengembangan Perikanan Budidaya Air Tawar. Jl. Raya Sempur No. 1, Bogor 16154, Indonesia. Tel.: + (0251) 8313200

E-mail: ofrijohan@kkp.go.id ekspedisi laut Siboga (1899-1900) memperlihatkan bahwa sedikitnya 555 dari 782 jenis rumput laut di Indonesia sudah berhasil diidentifikasi (Van Bosse, 1913 dalam Nontji, 1987). Sebaran alga laut ini sangat luas, yang ditemukan pada perairan dangkal laut di Indonesia, seperti Sumatera Utara, Riau, Lampung, Jawa Timur, Nusa Tenggara Barat, Nusa Tenggara 
Timur, Sulawesi, Bali, Biak, dan beberapa daerah provinsi lainnya (Parenrengi et al., 2010). Rumput laut yang sudah dimanfaatkan lebih dari 200 jenis dan dapat berperan dalam mendukung perekonomian nasional maupun internasional dalam produksi fikokoloid (alginat, agar, dan karaginan) dan makanan yang bernilai lebih dari US\$ 6,2 miliar (Zemke-White \& Smith, 2006). Selain itu, juga dimanfaatkan dalam bidang kosmetik, farmasi, dan industri seperti kertas, tekstil, fotografi, pasta, pengalengan ikan, anti-oksidan, dan sumber biogas, serta sebagai bioindikator dari status ekologi perairan (Anggadireja et al., 2011). Dari seluruh jenis rumput laut, 55 jenis di antaranya sudah dimanfaatkan oleh masyarakat di Indonesia sebagai bahan makanan dan sebagai obat-obatan secara tradisional terutama bagi masyarakat yang bermukim di daerah pesisir pantai (Parenrengi et al., 2010; Anggadireja et al., 2011).

Program industrialisasi perikanan oleh Kementerian Kelautan dan Perikanan telah menetapkan rumput laut sebagai salah satu komoditas unggulan dengan target produksi pada tahun 2015 mencapai 10 juta ton (Hadie, 2013). Produksi rumput laut telah berkontribusi dalam ekspor dengan nilai mencapai $62,22 \%$ dari total ekspor produk perikanan nasional, dengan negara tujuan ekspor di antaranya adalah Hongkong, Korea Selatan, Perancis, Inggris, Kanada, Amerika Serikat, dan Jepang (Parenrengi et al., 2010). Jenis rumput laut yang diekspor didominasi oleh jenis Euchema sp. dan Gracilaria sp. dari hasil budidaya, selebihnya merupakan rumput laut dari alam yaitu Sargassum sp., Turbinaria sp., dan Hypnea sp. (Hadie, 2013).

Pemanfaatan rumput laut yang cukup luas pada berbagai bidang dan memberikan peluang besar dalam pengembangan usaha budidayanya (Cornis \& Garbary, 2010; Orlando-Bonaca \& Lipej, 2009; Hughes et al., 2012; Septiana \& Asnani, 2013). Budidaya rumput laut secara komersial di Indonesia sudah dilakukan sejak tahun 1985 setelah teknologi budidaya rumput laut diperkenalkan di Filipina tahun 1971 (Ask \& Azanza, 2002). Volume ekspor rumput laut dalam bentuk kering dari Indonesia terus meningkat dari tahun 2002 hingga 2006 dengan laju peningkatan sebesar 71,67\% per tahun (Nurdjana, 2007).

Rumput laut hidup menempel di dasar perairan dangkal hingga kedalaman $180 \mathrm{~m}$ di atas substrat yang keras seperti batu cadas (rock), karang mati, kerikil, kerang-kerangan, dan tumbuhan, sebagian besar tidak bisa hidup pada lumpur dan pasir sebaliknya lamun akan menancapkan akarnya ke sedimen (Sahayaraj et al., 2014; Diaz-Pulido \& McCook, 2008). Rumput laut yang termasuk makroalga ini melakukan fotosintesis untuk menghasilkan makanan. Rumput laut merupakan salah satu vegetasi pantai yang berbeda dengan lamun dan tumbuhan bakau, karena tidak memiliki akar, bunga, dan jaringan seperti tumbuhan tingkat tinggi lainnya. Ukuran makroalga mulai dari beberapa millimeter hingga mencapai tinggi 3-4 m seperti Sargassum (Diaz-Pulido \& McCook, 2008). Dibandingkan dengan tumbuhan tingkat tinggi, makroalga memiliki siklus hidup yang kompleks dan beberapa cara untuk perkembangbiakannya. Sebagian besar alga berkembang biak secara seksual atau aseksual yaitu dengan menghasilkan gamet dan/atau spora, dan secara vegetatif melalui fragmentasi untuk mendapatkan individu baru (Parenrengi et al., 2010; Diaz-Pulido \& McCook, 2008).

Penelitian keterkaitan substrat perairan dengan keberadaan rumput laut sangat penting dilakukan untuk mengetahui habitat alam, sehingga dapat diaplikasikan dalam pemilihan lokasi dalam kegiatan budidaya rumput laut mengingat tingkat pemanfaatan yang tinggi dari alam dan pemenuhan kebutuhan dari hasil budidaya. Beberapa penelitian terkait keanekaragaman jenis rumput laut yang berasosiasi dengan substrat karang (Widyartini et al., 2011), makroalga di paparan terumbu karang Kepulauan Anambas dan perairan Kepulauan Bangka, Belitung, dan Karimata (Kadi, 2005; 2009).

Penelitian ini bertujuan untuk menganalisis hubungan distribusi jenis rumput laut alam dengan tipe substrat dasar perairan. Informasi kondisi alam dan sebaran dari jenis-jenis rumput laut alam, diharapkan dapat menjadi informasi dasar untuk pengembangan teknologi budidaya rumput laut, terutama jenis-jenis tertentu yang bernilai ekonomis tinggi, untuk mendukung peningkatan produksi rumput laut nasional.

\section{BAHAN DAN METODE}

Penelitian ini dilaksanakan pada bulan Oktober 2014 di pantai Ujung Genteng, Kabupaten Sukabumi Provinsi Jawa Barat. Lokasi pengamatan terbentang antara 7.34945 LS dan 106.40014 BT pada bagian Utara dan 7.38640 LS dan 106.40785 BT pada bagian Selatan (Gambar 1).

\section{Pengumpulan Data}

Desain titik pengamatan ditentukan dengan sistem informasi geografis (SIG) dengan total titik pengamatan sebanyak 146 yang disebar vertikal terhadap garis pantai mulai dari pinggiran pantai hingga ke arah tubir. Masing-masing titik pengamatan berjarak sekitar $50 \mathrm{~m}$. Lokasi pengamatan dikelompokkan menjadi tiga kawasan berdasarkan jarak dari garis pantai dan perbedaan karakteristik antar masing-masing kawasan tersebut. Kawasan-1 


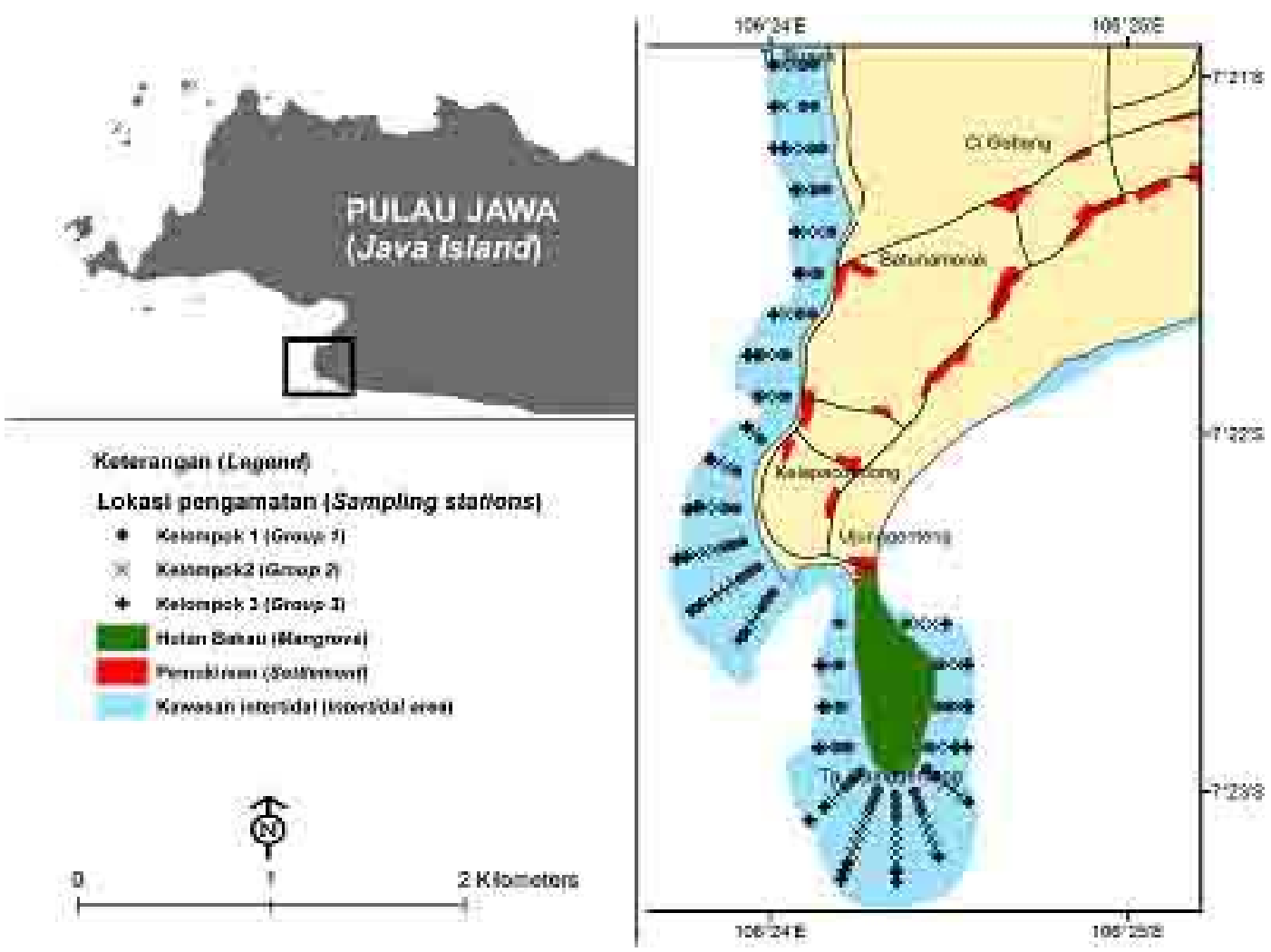

Gambar 1. Lokasi pengamatan jenis rumput laut, tipe substrat yang terbagi atas kelompok 1, 2, dan 3 menurut kedekatan dengan garis pantai

Figure 1. Observation sites of seaweed, substrate type which devided to group 1, 2, and 3 according to distance from the coastal line

berada pada area pinggir pantai hingga $100 \mathrm{~m}$ ke arah tengah, kawasan-2 terletak di pertengahan yaitu antara 100-300 m dari garis pantai, dan kawasan-3 berada di dekat tubir yaitu $>300 \mathrm{~m}$ dari garis pantai. Jumlah titik pengamatan untuk masing-masing kawasan disesuaikan dengan kondisi di lapangan, yaitu berturutturut 52, 57, dan 37 titik pengamatan. Kawasan-1 dicirikan oleh lokasi terdekat dengan garis pantai, tipe substrat didominasi oleh pasir, berada pada reef-flat (rataan terumbu), ombak lebih lemah, dan sering terekspos oleh pasang surut. Kawasan-2 dicirikan oleh tipe substrat berupa pasir dan karang, reef-flat, perairan lebih dalam dari lokasi kelompok 1 , ombak bisa mencapai lokasi ini, lebih sedikit terekspos baik luas dan lamanya dibandingkan dengan kelompok 1. Kawasan-3 dicirikan dengan lokasi paling luar atau pinggir reef-flat sebelum reef-edge, tempat pecahnya ombak, lokasi paling dalam dibandingkan kawasan-1 dan 2, substrat didominasi oleh karang dan pecahan atau batu karang, dan relatif selalu digenangi air atau jarang terekspos disaat surut terendah.

Pengumpulan data lapangan dilakukan dengan menggunakan metode transek kuadrat berukuran 1 $\mathrm{m} \times 1 \mathrm{~m}$ pada 146 titik pengamatan yang telah ditentukan. Data yang dikumpulkan terdiri atas jenis dan persentase tutupan dasar perairan yang meliputi rumput laut, lamun (L), pasir $(\mathrm{P})$, karang hidup $(\mathrm{K})$, pecahan karang (PK), dan batu karang (BK); dan jenisjenis rumput laut yang ditemukan, serta persentase tutupan masing-masing jenis. Identifikasi jenis rumput laut yang ditemukan mengacu pada Kalsum (2012) dan Ismail (1995).

\section{Analisis Data}

Hubungan antara tipe substrat dengan distribusi jenis rumput laut alam dianalisis dengan metode statistik multivariat yaitu dengan analisis diskriminan (discriminant analysis/DA) menggunakan software XLSTAT. Analisis diskriminan adalah salah satu metode statistik yang bisa digunakan pada hubungan dependensi, yaitu hubungan antar variabel di mana sudah bisa dibedakan antara variabel respons dan mana variabel penjelas. Analisis diskriminan bermanfaat pada situasi di mana total sampel dapat dibagi menjadi kelompok/grup berdasarkan karateristik variabel yang sudah diketahui. Tujuan 
utama dari DA adalah untuk mengetahui perbedaan antar kelompok. Pengelompokan individu dilakukan berdasarkan lebih dari satu variabel bebas (Legendre \& Legendre, 2003). Pengelompokkan dapat diketahui dari parameter lingkungan penciri dari masing-maing kelompok. Hasil pengujian statistik dapat menjelaskan keterkaitan antara penciri kelompok dengan keberadaan jenis-jenis rumput pada masingmasing kawasan.

\section{HASIL DAN BAHASAN}

\section{Distribusi Rumput Laut Alam}

Jenis rumput laut yang ditemukan di kawasan perairan Ujung Genteng, termasuk dalam tiga kelompok besar alga, yaitu alga merah (Rhodophyta), alga coklat (Phaeophyta), dan alga hijau (Chlorophyta). Berdasarkan hasil pengamatan di perairan Ujung Genteng, Sukabumi diperoleh lima jenis alga coklat, 14 jenis alga hijau, dan 15 jenis alga merah, di mana terdapat satu jenis yang belum dapat teridentifikasi yang termasuk dalam red turf algae. (Tabel 1). Alga coklat dapat ditemukan pada ketiga kawasan pengamatan. Sementara itu, terdapat beberapa jenis alga hijau yang ditemukan pada kawasan-2, namun tidak ditemukan pada kawasan-1 dan 3 yaitu jenis Valoniopsis pachynema, Neumeris anulata, dan Dictyosphaeria cavernosa. Selain itu, terdapat empat jenis alga hijau yang tidak ditemukan pada kawasan1 , namun dapat ditemukan pada kawasan-2 atau kawasan-3 (Tabel 1).

Berdasarkan hasil pengamatan di sepanjang perairan Ujung Genteng, ditemukan jumlah jenis alga coklat lebih sedikit dibandingkan jumlah jenis alga hijau dan alga merah. Perbandingan dengan lokasi lain di Indonesia, seperti di Kepulauan Anambas, hanya berhasil ditemukan enam jenis alga coklat, tujuh jenis alga hijau, dan lima jenis alga merah (Kadi, 2009). Total jenis makroalga ditemukan sebanyak 18 jenis di Kepulauan Anambas, 30 jenis di perairan Kepulauan Bangka, 101 jenis di Kepulauan Seribu (Atmadja \& Sulistijo, 1980; Kadi, 2005; 2009). Perairan Indonesia dan Malaysia keragaman makroalga dilihat dari jumlah jenis ditemukan berkisar antara 10-14 jenis (Grevo, 2004; Wong \& Phang, 2004). Sementara hasil penelitian melalui ekspedisi Sibolga pada tahun 18881889 menemukan 555 jenis makroalga di seluruh perairan Indonesia (Bosse, 1928). Perbedaan jumlah jenis ini tentunya terkait dengan luas cakupan wilayah penelitian, semakin luas cakupan wilayah penelitian dimungkinkan untuk menemukan jumlah jenis makroalga lebih banyak, seperti pada ekspedisi Sibolga.
Rata-rata tutupan tertinggi rumput laut dari kelompok alga coklat ditemukan pada kawasan-3 (39,60\%), kemudian diikuti oleh kawasan-1 (20,07\%), dan kawasan-2 (19,28\%) (Gambar 2). Kawasan di mana ditemukan alga coklat dengan tutupan yang relatif tinggi dicirikan dengan substrat yang terdiri atas pasir dan karang hidup, berada pada reef-flat di mana kondisi pecahan ombak bisa mencapai lokasi tersebut. Pengujian secara statistik menunjukkan perbedaan tutupan alga coklat berbeda nyata antar kawasan-3 dengan kawasan-1 dan $2(\mathrm{P}<0,05)$. Alga hijau memiliki tutupan tertinggi pada kawasan-2 (48,69\%), kemudian diikuti oleh kawasan-1 $(47,24 \%)$ dan kawasan-3 $(42,75 \%)$. Tutupan tertinggi alga merah ditemukan pada kawasan$1(32,69 \%)$, kemudian diikuti kawasan-2 (32,03\%), dan kawasan-3 (17,65\%). Berdasarkan data tersebut diketahui bahwa alga merah erat kaitannya dengan tipe substrat pasir dan berasosiasi dengan lamun yang ada di kawasan1 dan kawasan-2. Hasil analisis ragam memperlihatkan bahwa tutupan alga hijau dan alga merah antara ketiga kawasan tidak berbeda nyata $(\mathrm{P}>0,05)$. Alga hijau dan alga merah banyak ditemukan pada kawasan-1 dan 2 karena lokasi tersebut bersubstrat pasir dan pecahan karang, serta jauh dari pengaruh ombak.

Berdasarkan perhitungan persentase total tutupan rumput laut dari ketiga kawasan pengamatan, diperoleh tutupan tertinggi oleh alga hijau $(46,40 \%)$, kemudian diikuti dengan tutupan alga merah $(27,72 \%)$ dan alga coklat $(25,88 \%)$. Hasil pengamatan untuk masingmasing kawasan memperlihatkan bahwa rata-rata tutupan rumput laut tertinggi ditemukan pada kawasan-1 (38,77\%), kemudian diikuti kawasan-2 $(30,74 \%)$ dan kawasan-3 $(21,48 \%)$. Pengujian statistik dengan ANOVA menunjukkan bahwa keberadaan rumput laut antara ketiga kawasan sangat berbeda nyata $(\mathrm{P}<0,01)$. Hasil analisis data ini mengindikasikan bahwa semakin jauh dari pantai, ditemukan tutupan rumput laut yang semakin rendah.

Alga coklat memiliki kemampuan untuk beradaptasi karena memiliki lapisan lendir (mucus) yang dapat mengatasi kekurangan air, serta memiliki toleransi terhadap pasang surut yang lebih lama (DadolahiSohrab et al., 2012), sehingga pada perairan Ujung Genteng distribusinya dapat ditemukan berada pada ketiga kawasan pengamatan. Jenis alga yang paling banyak ditemukan di kawasan perairan Ujung Genteng adalah alga merah, yaitu 13 jenis ditemukan di kawasan2, 11 jenis di kawasan-3, dan sembilan jenis di kawasan-1. Sebaran alga di lokasi tersebut juga mengindikasikan bahwa terdapat beberapa jenis alga merah yang ditemukan pada salah satu kawasan pengamatan, namun tidak ditemukan pada kawasan pengamatan lainnya (Tabel 1). 
Tabel 1. Rata-rata tutupan jenis rumput laut (\%) pada tiga kawasan pengamatan di perairan Ujung Genteng, Jawa Barat

Table 1. Mean coverage of algae species on three observation areas in Ujung Genteng, West Java

\begin{tabular}{|c|c|c|c|}
\hline \multirow{2}{*}{$\begin{array}{l}\text { Jenis rumput laut } \\
\text { Seaweed species }\end{array}$} & \multicolumn{3}{|c|}{ Kawasan (Area) (\%) } \\
\hline & 1 & 2 & 3 \\
\hline \multicolumn{4}{|l|}{ Alga coklat (Phaeophyta) } \\
\hline Dictyota bartayresiana & 1.15 & 0.96 & 0.14 \\
\hline Padina sp. & 4.71 & 7.63 & 1.76 \\
\hline Sargassum sp. & 1.25 & 0.09 & 11.62 \\
\hline Hydroclathrus clathratus & 2.4 & 0.56 & 0.54 \\
\hline Turbinaria sp. & 3.27 & 1.05 & 13.05 \\
\hline \multicolumn{4}{|l|}{ Alga hijau (Chlorophyta) } \\
\hline Bornetella nitida & 2.37 & 2.7 & 1.81 \\
\hline Chaetomorpha sp. & 2.08 & 2.84 & 3.92 \\
\hline Halimeda simulans & 0.77 & - & - \\
\hline Halimeda micronesica & - & 0.47 & 2.97 \\
\hline Halimeda macroloba & - & - & 0.27 \\
\hline Halimeda sp. & 0.38 & 0.88 & 0.54 \\
\hline Ulva reticulate & - & - & 0.27 \\
\hline Ulva intestinalis & 2.08 & 2.84 & 3.92 \\
\hline Ulva lactuca & 8.94 & 12.12 & 13.24 \\
\hline Ulva fasciata & 5.48 & 9.79 & 11.35 \\
\hline Cladophora sp. & 1.06 & 0.88 & 2.51 \\
\hline Valoniopsis pachynema & - & - & 1.35 \\
\hline Neumeris anulata & 12.6 & 5.6 & 2.43 \\
\hline Dictyosphaeria cavernosa & - & 0.18 & - \\
\hline \multicolumn{4}{|l|}{ Alga merah (Rhodophyta) } \\
\hline E. spinosum & - & 0.26 & 0.14 \\
\hline Gracilaria foliifera & 10.58 & 16.49 & 12.03 \\
\hline Gracilaria salicornia & 4.71 & 5.35 & 2.92 \\
\hline Kappaphycus & - & 1.75 & - \\
\hline Jania adherens & 8.85 & 2.72 & 1.62 \\
\hline Acanthopora muscoides & 3.92 & 2.63 & 0.54 \\
\hline Hypnea cervicornis & 2.21 & 2.11 & 1.89 \\
\hline Hypnea asperi Bory & 1.54 & 2.32 & 0.78 \\
\hline Liagora divaricata & 9.04 & 2.37 & 3.51 \\
\hline Laurencia sp. & 1.15 & 1.05 & - \\
\hline Actinotrichhia fragilis & - & 0.18 & - \\
\hline Galaxaura subvefficillata & - & 1.05 & 1.62 \\
\hline Galaxaura rugosa & 0.38 & - & - \\
\hline Gelidium sp. & 1.54 & 2.72 & 0.41 \\
\hline Red turf alga & - & - & 3.65 \\
\hline
\end{tabular}

\section{Karekteristik Substrat Dasar Perairan}

Berdasarkan hasil analisis data tutupan substrat dasar perairan, pada kawasan-1 ditemukan tutupan lamun, pasir, karang hidup, dan pecahan karang yang lebih tinggi dibandingkan pada kawasan-2 dan 3
(Gambar 3). Tutupan lamun lebih tinggi pada kawasan yang lebih dekat ke arah pantai dan berkurang ke arah tubir (Gambar 3). Tutupan lamun pada masing-masing kawasan berturut-turut dari kawasan mulai dari pantai ke arah tubir adalah $37,29 \% ; 35,72 \%$; dan $8,92 \%$. Hasil 


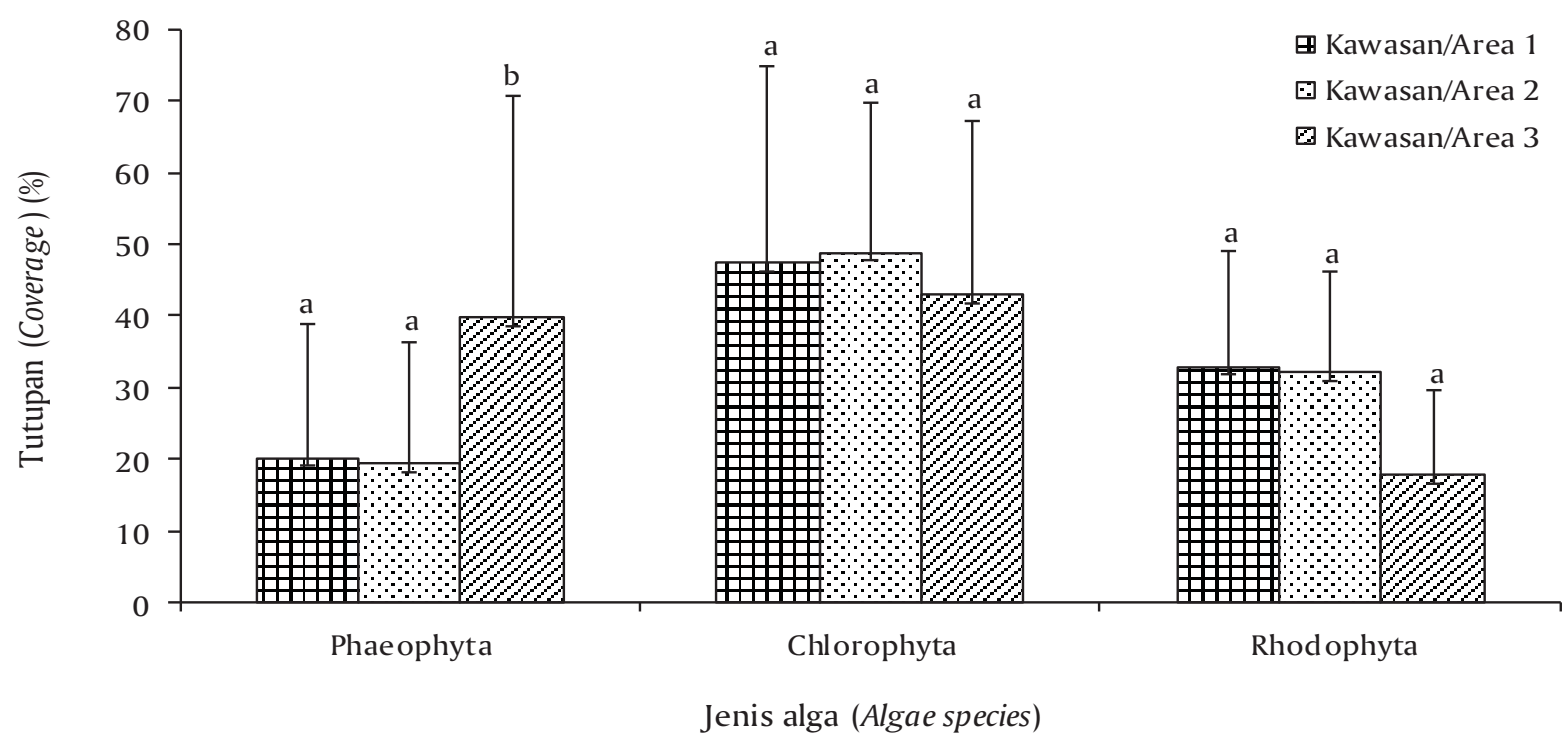

Gambar 2. Rata-rata tutupan alga coklat, alga hijau dan alga merah pada tiga kawasan pengamatan di perairan Ujung Genteng, Jawa Barat (huruf yang berbeda menunjukkan hasil uji yang berbeda nyata $(\mathrm{P}<0,05))$

Figure 2. Mean coverage of brown, green, and red algae on three observation area in Ujung Genteng coastal waters, West Java (different letters indicate the significant different of the test results $(P<0.05))$

analisis ragam terhadap tutupan lamun antara kawasan1 dan 2 menunjukkan hasil yang sangat berbeda nyata dengan kawasan-3 $(\mathrm{P}<0,01)$.

Secara keseluruhan, persentase tutupan dari masing-masing tipe substrat dasar perairan pada setiap titik pengamatan dari ketiga kawasan berkisar antara 0\%-90\%. Kisaran nilai ini berada pada jarak yang cukup lebar, yang mengindikasikan tingginya variabilitas tutupan untuk masing-masing tipe substrat dasar pada setiap titik pengamatan. Hal ini ditunjukkan dengan nilai standar deviasi yang sangat tinggi untuk masingmasing tipe substrat dasar tersebut (Gambar 3). Ratarata tutupan pasir pada masing-masing kawasan pengamatan berturut-turut adalah $20,50 \%$ (kawasan1), $18,77 \%$ (kawasan-2), dan 14,56\% (kawasan-3) (Gambar 3). Sama halnya dengan tutupan lamun, semakin menjauh dari pantai diperoleh tutupan pasirnya semakin berkurang. Pengujian statistik menunjukkan tidak terdapat perbedaan nyata $(\mathrm{P}>0,05)$ dari tutupan pasir antara ketiga kawasan pengamatan (Gambar 3). Hasil penelitian ini mempelihatkan bahwa tutupan lamun yang tinggi ditandai dengan keberadaan substrat pasir yang tinggi. Tutupan lamun dan keberadaan pasir semakin meningkat ke arah yang lebih dekat dengan garis pantai, sebaliknya karang hidup dan pecahan karang semakin berkurang. Hasil penelitian di perairan sekitar Pulau Pramuka dan beberapa lokasi lainnya ditemukan lamun pada substrat yang memiliki pasir sangat tinggi (Feryatun et al., 2012; Juraij-Bengen \& Kawaroe, 2014).

Tipe substrat karang hidup ditemukan lebih tinggi di kawasan-3 $(7,47 \%)$, kemudian diikuti oleh kawasan$2(4,68 \%)$, dan kawasan-1 (3,31\%) (Gambar 3). Hasil analisis ragam (ANOVA) menunjukkan bahwa tutupan karang hidup antar kawasan pengamatan tidak berbeda nyata $(P>0,05)$. Karang dapat hidup dengan baik di lokasi yang sering terkena ombak sehingga kebutuhan oksigen dan nutrien dapat terpenuhi secara optimal, dan pengendapan sedimen tidak terjadi karena selalu ada pergerakan air dengan adanya ombak. Selain itu, karang membutuhkan tipe dasar perairan yang keras yang umumnya lebih banyak ditemukan pada kawasan2 dan 3 dibandingkan kawasan-1. Berdasarkan pendapat ahli sebelumnya, makroalga dapat berasosiasi dengan habitat karang dan memiliki peran penting terhadap kesehatan dan kerusakan karang, serta dapat sebagai sumber makanan bagi hewan herbivora yang merupakan dasar dalam rantai makanan di ekosistem terumbu karang yang sangat penting secara ekologi dan ekonomi (Arthur, 1972; Diaz-Pulido \& McCook, 2008).

Rata-rata tutupan pecahan karang tertinggi ditemukan pada kawasan-3 (9,53\%), kemudian diikuti kawasan-2 (6,88\%) dan kawasan-1 (6,38\%). Data yang diperoleh saling mendukung dan menguatkan dengan 


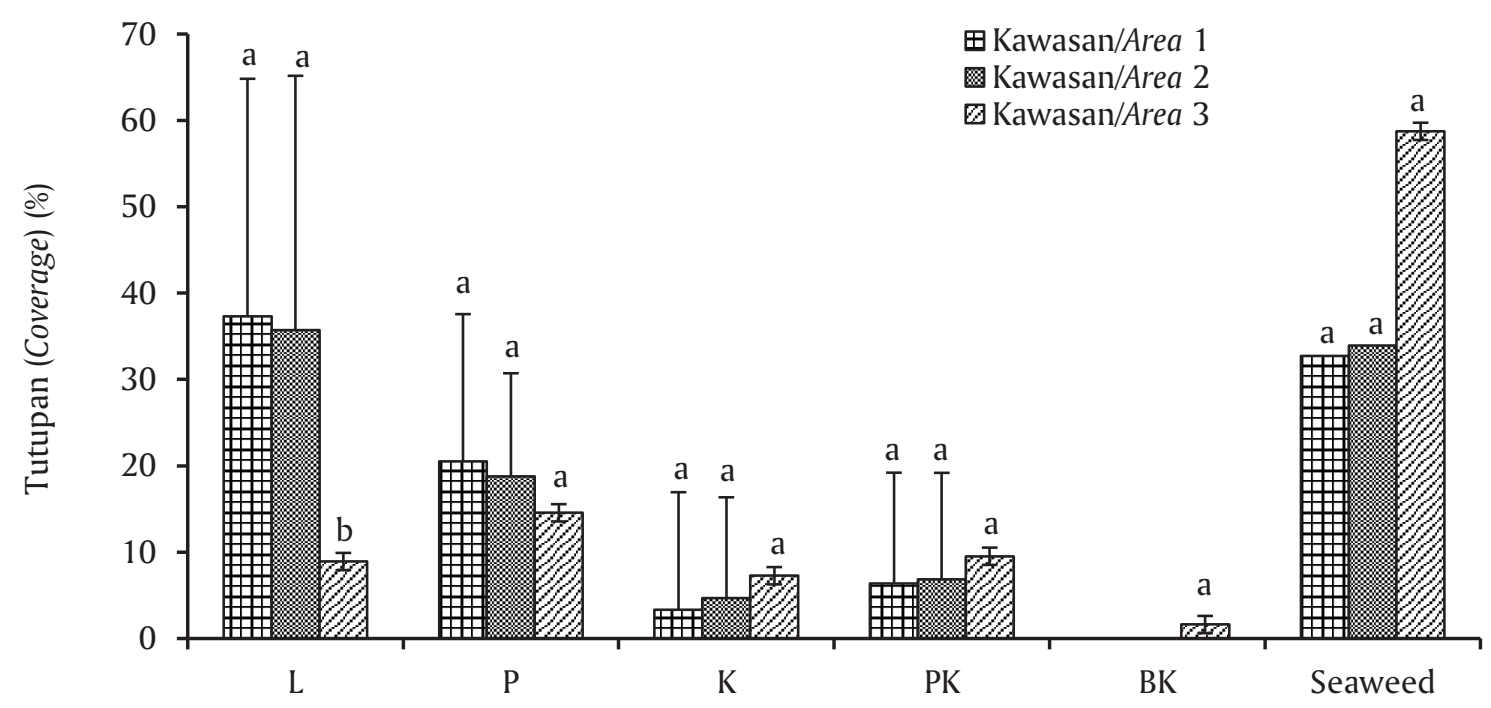

Tipe substrat (Substrate types)

Gambar 3. Rata-rata tutupan substrat dasar perairan pada tiga kawasan pengamatan di perairan Ujung Genteng, Jawa Barat (L: lamun, P: pasir, K: karang hidup, PK: pecahan karang, BK: batu karang, SW: seaweed) (huruf yang berbeda menunjukkan hasil uji yang berbeda nyata $(\mathrm{P}<0,05))$

Figure 3. Mean coverage of bottom substrate types on three observation area in Ujung Genteng coastal waters, West Java (L: seagrass P: sand, K: live coral, PK: rubble, BK: rock, SW: seaweed) (different letters indicate the significant different of the test results $(P<0.05)$ )

data sebelumnya yaitu keberadaan lamun dan pasir semakin tinggi ke arah daratan; sebaliknya semakin jauh dari pinggir pantai, tutupan karang hidup dan pecahan karang semakin tinggi. Hasil ANOVA menunjukkan tutupan pecahan karang tidak berbeda nyata antar kawasan $(P>0,05)$. Sementara tipe substrat batu karang tidak ditemukan pada semua lokasi, hanya terdata pada kawasan-3 dengan rata-rata tutupan $1,67 \%$. Batu karang merupakan karang mati yang berukuran besar dan tidak bisa teridentifikasi jenis karangnya karena skeletonnya telah terkikis atau berubah karena waktu kematian yang sudah lama. Pada kawasan-1 dan kawasan-2 tidak ditemukan batu karang, yang diduga sudah tertimbun oleh adanya pasir. Komunitas suatu perairan sangat cepat perubahannya seperti rataan terumbu di Pulau Hoga, Sulawesi Tenggara yang sebelumnya merupakan ekosistem terumbu karang, namun setelah sekitar 10 tahun mengalami perubahan menjadi hamparan pasir. Demikian juga di Pulau Pramuka di mana terumbu karang mengalami penurunan dalam kurun waktu 10 tahun sebesar 10,914 ha dan karang mati bertambah sebesar 2,269 ha (Manullang et al., 2014). Keberadaan karang mati merupakan penyumbang terbentuknya pasir di suatu perairan.
Pada area yang didominasi substrat pasir dan batu karang banyak ditemukan jenis Caulerpa dan Dictyosphaeria, sedangkan pada area dengan substrat karang mati ditemukan Hormophysa, Padina, Sargassum, dan Turbinaria (Kadi, 2009). Di sepanjang perairan Ujung Genteng ditemukan jenis Sargassum pada ketiga kawasan pengamatan. Hasil penelitian Kadi (2009) pada tiga pulau di Kepulauan Anambas, yaitu Pulau Jemaja, Pemutus, dan Matak, sebagian makroalga yang ditemukan di area tubir (bagian terluar) adalah jenis Sargassum yang tumbuh pada substrat keras berupa batu karang.

Rumput laut memiliki persyaratan yang spesifik akan kebutuhan terhadap nutrien, cahaya, air, karbon dioksida, dan ruang. Kompetisi akan terjadi apabila ketersedian faktor-faktor tersebut terbatas. Jenis rumput laut yang ditemukan pada kawasan- 1 akan memiliki kemampuan tahan terhadap kekeringan pada saat terjadi surut, kondisi dasar perairan yang bersedimen dan keruh, keterbatasan berfotosintesis karena kurang cahaya saat air keruh. Sementara itu, jenis rumput laut yang ditemukan pada kawasan-3 akan memiliki kemampuan adaptasi terhadap pecahan ombak dan gelombang. Jenis rumput laut yang berbeda akan memiliki kemampuan terbaik agar bisa bertahan 
di lokasi yang berbeda dengan cara seoptimal mungkin (Dadolahi-Sohrab et al., 2012).

\section{Hubungan Distribusi Rumput Alam dengan Karakteristik Substrat Dasar Perairan}

Hasil analisis diskriminan terhadap hubungan distribusi rumput laut alam dengan komponen tutupan substrat dasar perairan Ujung Genteng ditampilkan pada Gambar 4. Berdasarkan hasil analisis, diperoleh ragam kumulatif dari sumbu pertama dan sumbu kedua mencapai $100 \%$, dengan keragaman data yang dapat dijelaskan oleh masing-masing sumbu adalah $92,44 \%$ untuk sumbu pertama dan 7,56\% untuk sumbu kedua (Gambar 4). Hal ini menunjukkan bahwa dengan pengelompokkan lokasi pengamatan menjadi tiga kawasan, hubungan tipe substrat dasar dengan keberadaan jenis rumput laut dapat dijelaskan dengan baik hanya dengan dua sumbu tanpa ada kehilangan informasi. Sumbu pertama dan kedua memiliki nilai akar ciri 0,302 dan 0,025. Pengujian dengan menggunakan $\mathrm{F}$ Fisher untuk mengetahui perbedaan tutupan substrat antara ketiga kawasan diperoleh hasil bahwa terdapat perbedaan antara kawasan-1 dengan 3, antara kawasan-2 dan 3, namun tidak terdapat perbedaan antara kawasan-1 dan 2 pada tingkat ketelitian $95 \%$.
Sumbu pertama dicirikan oleh adanya tutupan lamun (L:-0.874), alga coklat $(0,628)$, pasir ( $\mathrm{P:}-0,343)$, pecahan karang (PK: 0,182), batu karang (BK: 0,296); sementara sumbu kedua dicirikan oleh alga merah $(0,382)$, alga hijau $(0,255)$, dan karang $(-0,283)$ (Gambar 4). Semakin tinggi angkanya maka dapat diinterpretasikan bahwa tingkat korelasinya sangat tinggi, dan apabila tipe substrat berdekatan dengan salah satu jenis alga menunjukkan keberadaan salah satu jenis alga dicirikan oleh tipe substrat yang berdekatan tersebut.

Berdasarkan Gambar 4 dapat dijelaskan hubungan antara keberadaan alga dengan tipe substrat dasar. Semakin panjang garis atau tingginya angka koordinatnya dan semakin berdekatan garis satu dengan garis yang lain menunjukkan hubungan yang lebih dekat. Keberadaannya alga merah dicirikan oleh adanya substrat pasir, namun tingkat keterkaitannya tidak tinggi dilihat dari panjang garis atau titik koordinat yang masih dekat dengan titik 0 . Keberadaan alga merah berbanding terbalik dengan tipe substrat pecahan karang dan karang. Keberadaan alga coklat lebih dicirikan oleh adanya substrat keras esperti batu karang dan pecahan karang, serta karang hidup. Sementara itu, distribusi alga hijau bersifat lebih luas, karena dapat ditemukan hampir pada semua tipe substrat dasar dengan kepadatan tutupan yang berbedabeda antar jenis, morfologi, dan cara penempelannya.

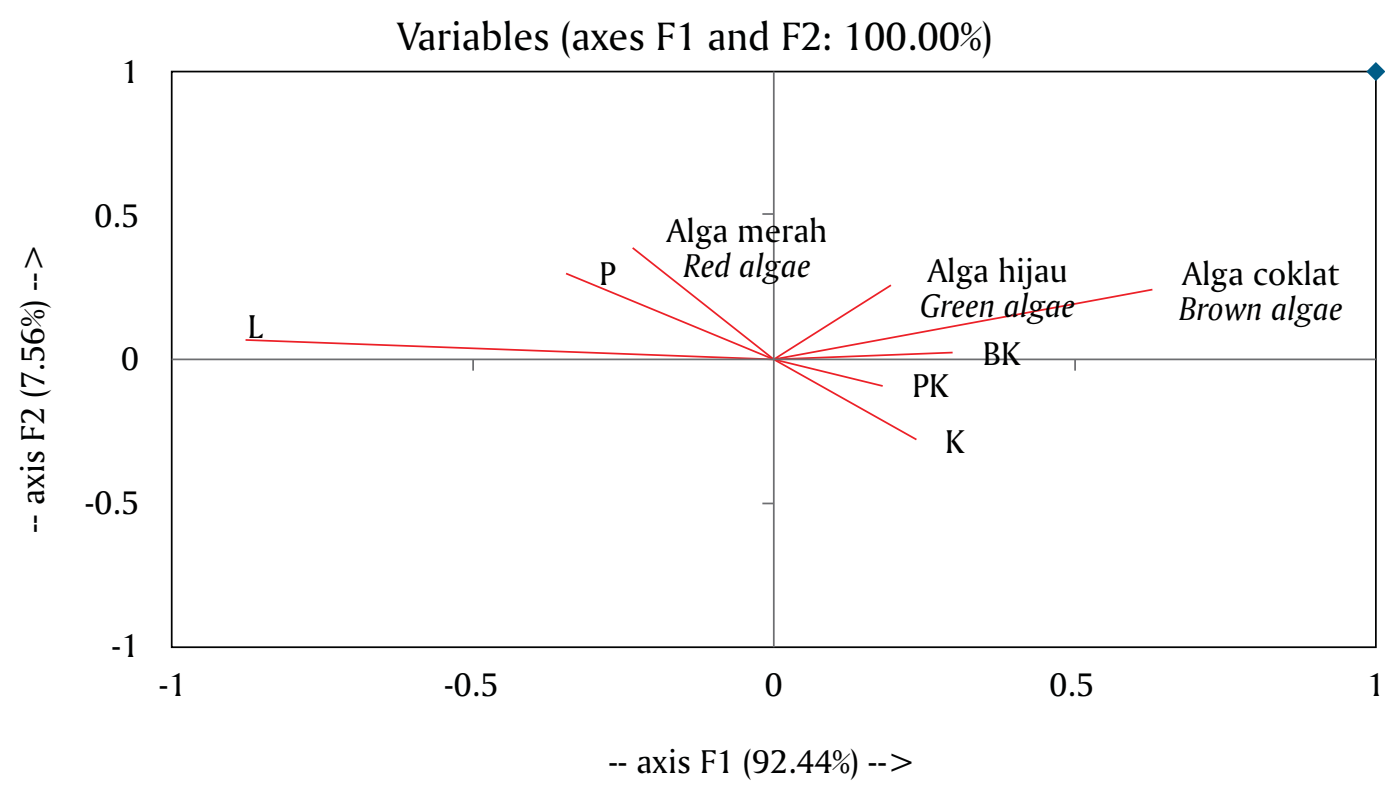

Gambar 4. Hasil analisis diskriminan hubungan tutupan rumput laut dengan tipe substrat dasar perairan Ujung Genteng, Jawa Barat (L: lamun, P: pasir, K: karang hidup, PK: pecahan karang, BK: batu karang)

Figure 4. Discriminant analysis result for correlation between seaweed coverage and bottom substrate types in Ujung Genteng coastal waters, West Java (L: seagrass P: sand, K: live coral, PK: rubble, BK: rock) 


\section{KESIMPULAN}

Tipe substrat dasar perairan sangat berperan dalam menentukan keberadaan jenis rumput laut alam di perairan Ujung Genteng, Jawa Barat. Jenis rumput laut dari kelompok alga coklat umumnya banyak ditemukan pada kawasan perairan yang berada dekat dengan tubir yang dicirikan oleh substrat keras berupa batu karang dan pecahan karang, dengan kondisi yang lebih banyak terkena pecahan ombak dan masih digenangi air pada saat surut. Jenis alga merah lebih banyak ditemukan pada area dengan tipe substrat berpasir, sedangkan alga hijau tersebar hampir di seluruh kawasan dengan berbagai tipe substrat dasar. Data sebaran rumput laut dan tipe substrat dasar perairan yang sesuai untuk pertumbuhan rumput laut akan menjadi informasi awal yang sangat penting untuk mendukung pengembangan teknologi budidaya dan kesesuaian lahan untuk budidaya rumput laut di masa yang akan datang.

\section{UCAPAN TERIMA KASIH}

Terima kasih disampaikan pada Dr. Joni Haryadi dan anggota KIMBIS Ujung Genteng atas bantuan dalam pelaksanaan survai lapang dan semua pihak yang turut melancarkan kegiatan survai sehingga diperoleh data yang bermanfaat dalam pembuatan tulisan ini. Penelitian ini dibiayai dari anggaran DIPA Pusat Penelitian dan Pengembangan Perikanan Budidaya tahun 2014.

\section{DAFTAR ACUAN}

Anggadireja, J.T., Widodo, M.M.A., Arfah, A., Zatnika, A., Kusnowirjono, S., Indrayani, I., Ma'mun, D., Samila, \& Hadi, S. (2011). Kajian strategi perkembangan industri rumput laut dan pemanfaatannya secara berkelanjutan. BPPT Press. Jakarta, 102 hlm.

Arthur, M.R.H. (1972). Geographycal, ecology, pattern in the distribution of species. Happer \& Row, Publ., New York, 269 hlm.

Ask, E.I., \& Azanza, R.V. (2002). Advances in cultivation technology of commercial eucheumatoid species: a review with suggestions for future research. Aquaculture, 206, 257-277.

Atmadja, W.S., \& Sulistijo. (1980). Alga bentik. dalam: Moosa, M.K., Kastoro, W., \& Romimohtarto, K. (Eds.). Peta sebaran geografik. Beberapa biota laut perairan Indonesia. Lembaga Oseanologi NasionalLIPI. Jakarta, hlm. 42-51.

Bosse, A.W.V. (1928). Liste des algues du Siboga Rhodophyceae traisimi partie Gigartinales et Rhodymeniales. Leiden, E.J. Brill. Siboga Expeditie LIXd, 533 pp.
Cornis, M.L., \& Garbary, D.J. (2010). Antioxidants from macroalgae: potential applications in human health and nutrition. Algae, 25(4), 155-171.

Dadolahi-Sohrab, A., Garavand-Karimi, M., \& Riahi, Pashazanoosi, H. (2012). Seasonal variations in biomass and species composition of seaweeds along the northern coasts of Persian Gulf (Bushehr Province). J. Earth Syst. Sci., 121(1), 241-250.

Diaz-Pulido, G., \& McCook, L. (2008). Macroalgae (Seaweeds). In: Chin, A. (Ed.). The state of the great barrier reef on-line, great barrier reef marine park authority. Townsville, $44 \mathrm{pp}$.

Feryatun, F., Hendrarto, B., \& Widyorini, N. (2012). Kerapatan dan distribusi lamun (seagrass) berdasarkan zona kegiatan yang berbeda di perairan Pulau Pramuka, Kepulauan Seribu. Journal of Management of Aquatic Resources, hlm. 1-7.

Grevo, S.G. (2004). Biodiversity of Indonesian seaweeds. In: Phang, S.M., Ching, C.V., Chye, H.S., Mokhtar, N.H., \& Sim, J.O.L. (Eds.). Marine science into the millenium, new perspectives and challenges. Proceeding of the Asia Pacific Conference on Marine Science \& Technology. Kuala Lumpur, hlm. 47-54.

Hadie, L.E. (2013). Analisis prospek budidaya rumput laut alam potensial dalam mendukung industrialisasi perikanan. Analisis kebijakan pembangunan perikanan budidaya 2013. Pusat Penelitian dan Pengembangan Perikanan Budidaya. Jakarta, hlm. 1-9.

Hughes, A.D., Kelly, M.S., Black, K.D., \& Stanley, M.S. (2012). Biogas from Macroalgae: is it time to revisit the idea? Biotechnology for Biofuels, 5, 86.

Ismail, A. (1995). Rumput laut Malaysia. Dewan Bahasa dan Pustaka, Kementerian Pendidikan Malaysia. Kuala Lumpur, 277 pp.

Juraij-Bengen, D.G., \& Kawaroe, M. (2014). Keanekaragaman jenis lamun sebagai sumber pakan dugong dugon pada Desa Busung Bintan Utara, Kepulauan Riau. Omni-Akuatika, XIII(19), 7176.

Kadi, A. (2005). Makroalga di Perairan Kepulauan Bangka, Belitung, dan Karimata. Universitas Diponegoro. Jour. Mar. Sci., 10, 98-105.

Kadi, A. (2009). Makroalga di paparan terumbu karang Kepulauan Anambas. Jurnal Natur Indonesia, 12(1), 49-53.

Kalsum, S.J. (2012). Jenis-jenis rumput laut. Seaplant.net., $100 \mathrm{hlm}$.

Legendre, P., \& Legendre, L.F.J. (2003). Numerical ecology: development in environment modeling 20. Second English Edition. Elsevier, 853 pp. 
Manullang, J.P., Hartoni, \& Surbakti, H. (2014). Analisis perubahan luasan terumbu karang dengan menggunakan data penginderaan jauh di perairan Pulau Pramuka Kabupaten Administratif Kepulauan Seribu. Maspari Journal, 6(2), 125-132.

Nontji, A. (1987). Keanekaragaman hayati laut Indonesia. Lembaga Ilmu Pengetahuan Indonesia.

Nurdjana, M.L. (2007). Program pengembangan dan pemberdayaan perikanan budidaya lima tahun ke depan. Makalah disampaikan pada Rakernis Pusat Riset Perikanan Budidaya (PRPB) di Yogyakarta, 2627 Juli 2007. $29 \mathrm{hlm}$.

Orlando-Bonaca, M., \& Lipej, L. (2009). Benthic macroalgae as bioindicators of the ecological status in the Gulf of Trieste. Varsto Narave, 22, 6372.

Parenrengi, A., Rachmansyah, \& Suryati, E. (2010). Budidaya rumput laut, penghasil karaginan (Karaginofit). Badan Penelitian dan Pengembangan Kelautan dan Perikanan. Kementerian Kelautan dan Perikanan. ISBN: 978-979-3692-21-0. $54 \mathrm{hlm}$.

Sahayaraj, K., Rajesh, S., Asha, A., Rathi, J.M., \& Raja, P. (2014). Distribution and diversity assessment of the marine macroalgae at four southern districts of Tamil Nadu, India. Indian Journal of GeoMarine Sciences, 43(4), 607-617.

Septiana, A.T., \& Asnani, A. (2013). Aktivitas antioksidan ekstrak rumput laut. Jurnal Teknologi Pertanian, 14(2), 79-86.

Widyartini, D.S., Insan, H.A.I., \& Sulistyani. (2011). Keanekaragaman spesies rumput laut coklat (Phaeophyceae) pada substrat karang pantai Menganti, Kebumen. Prosiding Seminar Nasional Hari Lingkungan Hidup, hlm. 88-92.

Wong, C.L., \& Phang, S.M. (2004). Diversity and distribution of Malaysian Sargassum sp. In: Phang, S.M., Ching, C.V., Chye, H.S., Mohktar, N.H., \& Sim, J.O.L. (Eds.). Proceeding of the Asia-Pacific Conference on Marine Science \& Technology. Kuala Lumpur, p. 23-46.

Zemke-White, W.L., \& Smith, J.E. (2006). Environmental impacts of seaweed farming in the tropics. In: Critchley, A.T., Ohno, M., \& Largo, D. (Eds.). World Seaweed Resources. Expert Centre for Taxonomic Identification (ETI), University of Amsterdam (CDROM series). 